\title{
The Covid-19 pandemic: collective action and European public policy under stress
}

\begin{abstract}
The European continent faces an apocalyptic pandemic that poses mortal danger to millions of citizens. This paper seeks to address the role played by European public policy in addressing the Covid-19 pandemic. Currently, each Member State across Europe is applying its own measures to deal with the coronavirus; namely, decentralised decision-making that could trigger political tensions among the states. The paper argues that European public policy must change rapidly and fundamentally if these tensions are to be successfully managed; otherwise, such policy might simply cease to exist. Moreover, the known and notorious problem of collective action, information asymmetries, irrationality, negative externalities and the related free-riding phenomenon persistently are distorting the Member States' combined efforts, resulting in deficient attempts to contain the spread of Covid-19. The paper also argues that the current unprecedented outbreak of this superspreading virus calls for a bigger EU-wide coordinated response. We argue that the Covid-19 pandemic is a good example of an area in which the central EU level holds a comparative advantage over lower levels of government. In addition, the paper offers several substantive insights into ways to improve the public policy response in the 'war' against Covid-19.
\end{abstract}

KEYWORDS: Covid-19 pandemic, negative externality, collective action problem, coordination, economics of federalism

JEL CLASSIFICATION: C23, C26, C51, K42, O43

RECEIVED 14 April 2020; ACCEPTED 13 August 2020.

\section{INTRODUCTION}

The coronavirus pandemic is a human tragedy of potentially biblical proportions and Europe is one its epicentres. A shocking rising number of infected and deceased citizens are overflowing the entire healthcare systems with the seemingly unstoppable character of this superspreading pathogen bringing the European Union (EU) to its knees. The sporadic, sometimes even panicky, actions being taken by governments in an attempt to relieve their overburdened health systems are anecdotal, sometimes opposed by the general population and yet necessary. However, the different approaches adopted today by the Member States (MS) might not work without the efforts being coordinated at the central EU level. While most European countries are closing bars, restaurants, schools and even (partially) borders, some are carrying on like nothing has happened. This piecemeal, nation-by-nation approach and the lack of coordinated public policy is one of the biggest threats the EU has ever faced to its existence. Reports of growing Euroscepticism in Italy and other countries hit hard by the coronavirus and the exponential rise of nationalism are further proofs of disillusioned EU citizens who have lost faith and trust in European (but also national) institutions (Diamanti, 2020).

The EU is seen as having abandoned Italy in its hour of need when, in a shameful abdication of responsibility in the first weeks of the outbreak, fellow EU countries failed to provide medical assistance and supplies to Italy (Braw, 2020). Thus, European public policy must change fast and fundamentally or simply cease to exist. A concerted and well-coordinated policy response at both the national and European levels is required to limit economic, social and health damage and re-establish financial stability (Regling, 2020). Namely, as Verhofstad (2020) states, it has long been clear that the EU is powerless in the face of exceptional circumstances and, for instance, has been unable to bring the migration crisis under control. Verhofstad (2020) argues that the Covid-19 pandemic

1 University of Ljubljana School of Economics and Business

2 Erasmus University Rotterdam Erasmus School of Law 
exposes Europe's lack of trust on an entirely new level: 'Italy's cry for help to replenish something as basic as mouth masks, remained for weeks unanswered by all other European Member States'. Insightfully, former EU Commission President Jacques Delors remarked that 'the germ of division is back', and that 'the climate that seems to hang over the heads of state and government and the lack of European solidarity pose a mortal danger to the European Union' (Delors, 2020). In other words, in Europe, each MS is applying its own measures to address the pandemic. This entails decentralised decision-making and results in a range of sometimes contradictory policies, as opposed to centralised decision-making leading to a coordinated effort and policy approach.

This paper joins this critical debate and attempts to show that the insights brought by considering the intertwined collective action phenomenon and the economics of federalism may help expand the toolkit for structuring the current discussions on the pandemic. Namely, the superspreading nature of Covid-19 may be seen as a traditional negative 'externality' and the population's health (containing or reducing its severity) as a collective good problem. The provision of such a collective good is undermined by the notorious collective action problem which refers to the fact that even when it may be in the interest of a group of states to organise and coordinate their containment/mitigation action, each MS may 'free ride' and go about its business, without making the effort required to protect the group's interest. For example, in the current institutional framework, neither the European Directorate for Health and Food Safety nor the European Medicines Agency has the authority to act, and they can merely issue recommendations. Accordingly, it is up to the 27 health ministers of the MS to take over and launch decisive action. However, the notorious problem of collective action and the related free-riding phenomena are distorting any such collective effort and leading to the suboptimal performance of individual MS actions. Such free riding then requires institutionalised power and a central coordinated effort to mitigate the collective action problem. Hence, the containment or mitigation of severity should become (or already has been) a competence of EU-coordinated law making. In other words, in today's EU institutional structure, the collective action problem together with the suboptimal vertical allocation of competences might be additional sources of the political breakdown currently being seen among the 27 MS. This paper suggests that if we are to successfully contain the spread of Covid-19 or reduce its severity, we indeed need 'more' Europe. Moreover, the probability of second and third waves of the Covid-19 outbreaks means that it is even now not too late to take the steps we are suggesting.

This paper also contributes to the literature by offering alternative insights to the further complicating problem of why people are not listening to government instructions to self-isolate at home unless they are enforced by sanctions.

The analysis presented here is both positive and normative. The analytical approach entails interdisciplinary analysis and enriches it with the concepts used in the economic analysis of law (De Geest, 2011; Posner, 2011; Shavell, 2004; van den Bergh, 2018: 21). However, several caveats should be issued. Namely, this paper only addresses the collective action problem among the EU MS and does not consider the pandemic's economic impact in terms of financial instability, recession, lower incomes or policy challenges at the national and European levels. Moreover, the paper does not discuss the effectiveness of regulatory instruments and is not investigating the distinctions between different phases of outbreaks (e.g. between (a) the lockdown phase and (b) the start-up phase).

This paper is structured as follows. Part one provides an economically inspired conceptual framework revealing that the coronavirus contagion may be seen as a classic negative externality problem. It is also argued that the collective action phenomenon, information failures, irrational choice and the free-riding problem may help expand the toolkit by providing additional insights for structuring the current discussion on the pandemic. The second part offers a set of recommendations for an improved regulatory intervention and shows that the Covid-19 pandemic calls for supranational EU-coordinated public policy. It also offers several solutions to the identified collective action problem, irrational choice and information failures. Finally, brief conclusions are presented.

\section{CONCEPTUAL FRAMEWORK}

Economically speaking, the Covid-19 pandemic and the superspreading nature of this pathogen is a classic example of a negative externality and the 'tragedy of the commons'. Namely, the problem of positive transaction costs and asymmetric information leads to so-called market failures (Akerloff, 1970) that cause a suboptimal (inefficient) level of economic activity and inefficient resource allocation. The collective action problem, the agency problem, the tragedy of the commons and game theory's prisoner's dilemma are the notorious embodiment of positive transaction costs and asymmetric information problems that generate negative externalities and, relevant to our discussions, also the suboptimal/inefficient level of public action and Covid-19's contagion. The materialisation of these negative externalities accompanied by the 'failure of private law' prima facie warrants regulatory intervention in the public 
interest (Ogus, 2004). In other words, allocative efficiency and optimal human behaviour will only emerge if the decision-making process achieves $100 \%$ internalisation of all external costs and benefits. Yet, because on aggregate, people are self-interested, maximise their own welfare and not everyone suffers the health costs of being infected (asymptomatic symptoms of Covid-19), such internalisation of the costs of people's behaviour (by infecting others) tends to be suboptimal.

This section offers an economically inspired conceptual framework to show that the coronavirus contagion may be seen as a classic negative 'externality' (and in public health as a collective public good issue) that creates problems with cooperation, informational failures, irrational choice, individual free riding and the tragedy of the commons.

\section{Coronavirus contagion as a systemic negative externality and the problem of collective public goods}

The specific phenomenon with multiple sub-parts of interest to us while investigating the Covid-19 pandemic is of external effects or externalities, also known as spillover effects. A negative externality arises when one person's decision impacts someone else where no institutional mechanism exists to induce the decision-maker to fully account for the spillover effect of their action or inaction (Leitzel, 2015; Viscusi, 2007, 1992; Coase, 1959, 1960; Pigou, 1932). These negative externalities can also trigger market failures given that the generator of the externality incurs no cost for the harm they cause others, making them exercise inadequate self-restraint (Cooter and Ulen, 2016: 40-42; Miller et al., 2017; Hirshleifer, 1984). In other words, the private cost for the person creating the negative externality is lower than the social cost, which is the sum of that private cost plus the costs incurred by third persons (Pigou, 1932; MacKaay, 2013). Corresponding public policies are then some of the most effective remedies for correcting this failing. Hence, the institutional response and political decision-making should aim to internalise these negative externalities, forcing decision-makers (the population) to respond to the impacts of their choices upon others as if they were felt by the decision-maker directly (Leitzel, 2015). The inadequate internalisation of such negative externalities could also manifest as the notorious tragedy of the commons. Coined by Hardin (1968) and Gordon (1954), the tragedy of the commons concept suggests that individuals might not see themselves as being responsible for common resources like public health and might eventually destroy such shared resources (Demsetz, 1967).

Extrapolating the concepts of negative externality and 'the tragedy of the commons' to the Covid-19 pandemic allows us to argue that the Covid-19 contagion should be regarded as a systemic negative externality where the actions of individuals and certain EU MS affect bystanders and other MS. Namely, the generator of one externality - a Covid-19-infected person - who does not incur any cost for harming others and thus exercises too little self-restraint (not following the social distancing instructions). He or she acts if the cost of spreading Covid-19 is zero when, in fact, there are real and considerable costs involved (e.g. for stress), as those people infected by such a person (ultimately ending in severe pneumonia in intensive care) can testify. Yet, this suboptimal level of self-isolation and social distancing is even more acute when an infected person shows no symptoms. Economically speaking, asymptomatic Covid-19 contagion introduces serious informational asymmetry and can even exacerbate the negative externality problem. Namely, by lacking information about their health status, an already infected person has no idea that they are possibly spreading the virus and harming others. Hence, the problem of a suboptimal level of self-restraint is greatly amplified and leads to a socially disastrous quantity of negative externalities (i.e. superspreading of the pathogen).

Moreover, an environment which is not infected by the Covid-19 pathogen (no contagion) may be regarded as a collective public good (Katz and Rosen, 1997; Kreps, 1990). Such a non-infected environment (or an MS) free of contagion or where the spread has been successfully contained (yet the virus may reactivate, making this issue hugely problematic, since multiple tests over time will be needed) is a non-rivalrous and non-excludable commodity where the internalisation of negative externalities is problematic (Magen, 2015: 78; Fudenberg and Tirole, 1996). For this reason, both individuals and certain MS have a strong inducement to try to free ride. They might hope to benefit at no cost to themselves with respect to the payment and effort of others.

Further, since individuals and MS might not see themselves as being responsible for an uncontaminated environment or for the non-spread of the pathogen, they could eventually destroy such a common resource, with a terrible ending. In other words, the tragedy of the commons might eventuate and distort any effective containment of the spread of Covid-19 or mitigation of its severity (Hardin, 1975; Eggertsson, 1990). 


\section{The collective action problem among EU MS}

On the top of creating conflicts between individual and collective rationality, the negative externalities discussed above are also a major source of cooperation difficulties. The collective action problem refers to the fact that even when it may be in the interest of a group of people to organise and coordinate their action, each member of that group might free ride and go about their business without exerting the effort needed to protect the group's interest, or may even remain unaware of what is going on. Namely, in many situations, people or governments decide on an action based in part on how others are likely to behave. In politics, business, legal and social interactions, parties frequently consider the anticipated behaviour of others while making their decisions (Jackson et al., 2003). Game theory deals with such situations and also identifies the 'collective action problem' (Schelling, 1960; Luce and Howard, 1957). Modern game theory, now highly developed, is a general analytical theory of rational choice in strategic interactions and provides a useful, flexible way to organise thinking about strategic decision-making (Dixit and Nalebuff, 1991). It enhances our understanding of different types of rules and institutions and focuses on decision-making situations characterised by strategic interdependence which occur when an actor must take this interdependence into account while making a rational choice (Magen, 2015).

Insightfully, game theory's notion of the 'prisoner's dilemma' with multiple players suggests that the problem of collective action might materialise (Elster, 2007; Luce and Howard, 1957). Namely, when a group of individuals or states has a common goal whose achievement would benefit all of them, it does not automatically follow that each will necessarily help to accomplish the goal (Taylor, 1987; Elster, 2007). Game theory informs that cooperation might not be forthcoming when a player can profit from cheating or tricking others, and each player, fearing to become the victim of such a choice by another, withholds their cooperation (MacKaay, 2015; Olson, 1965). For example, if an MS (or individual citizens) contributes nothing to the containment or mitigation of the severity of Covid-19 pandemic but shares in the benefits as much as all the others, once the goal of isolating/controlling the outbreak has been achieved, one must expect some will be tempted to free ride on the efforts of others. This free riding may cause cooperation towards the common goal to fail, and the individual rationality at play may lead to collective ruin (Cohen, 1991).

In other words, coordinated action in containing or reducing the severity of this pandemic benefits all MS; yet states (and citizens) might have a unilateral incentive to deviate from collectively taking action.

Moreover, as North (1990) suggests, the necessary condition for instrumental rationality in the MS decision-making process is hindered by the political markets where the negative externalities from policy choices posit the source of short-run opportunistic rents (combined with ideology) that result in suboptimal political choices. These political transaction costs (North, 1990) generated by the MS currently materialise as a barrier to fast and rapid policy response to the Covid-19 outbreak.

Furthermore, the observed collective action problem might be amplified by the absence of shared mental models (Denzau and North, 1994). Namely, the absence of shared mental models might be a mechanism behind the MS collective action failure. The notion of a shared mental model is well known in the literature regarding teamwork among humans (Mathieu et al., 2000). It has been used to explain team functioning. The idea is that team performance improves if team members have a shared understanding of the task that is to be performed and of the involved teamwork (Denzau and North, 1994). In such setting, the MS might gain from the status quo of decentralised decision-making, since a decrease in the political transaction costs that may induce EU-wide better provision of public goods increases the rents that can be appropriated by their political opponents. Although the question of how a shared mental model might be acquired in the EU to facilitate more effective responses to the Covid-19 pandemic exceeds the scope of this paper, one may theorise that perhaps varying levels of per capita income reflect a plethora of different interests among the MS. The absence of shared mental model might even imply that the departure from the feasible and optimal policy choices that underline the liberal democratic setting (Mukand and Rodrik, 2020) might be very likely since the conditions for the economic and political union depart from the interest of the MS.

\section{Irrational behaviour, biases and cognitive psychology}

The observed behavioural inconsistencies and apparent shortcomings of the conventional economic approach have encouraged some scholars to investigate the motivation underlying the behaviour of people in order to improve existing theories and make more accurate predictions (Simon, 1981; Ellsberg, 1961; Schelling, 1960; Markowitz, 1952a, 1952b; Allais, 1953). In 1979, Kahneman et al. published their ground-breaking articles on prospect theory in which they introduced fundamental concepts in relation to 
reference points, loss aversion, utility measurement, mental accounting and subjective probability judgements (Kahneman and Tversky, 1979; Thaler, 1980). Behavioural law and economics argues that persons display bounded rationality and they (a) suffer from certain biases, like over-optimism and self-serving conceptions of fairness; (b) follow heuristics, like availability, that lead to mistakes; (c) display incomplete self-control that induces individuals to make decisions in conflict with their long-term interest and (d) behave according to prospect theory rather than expected utility theory (Jolls et al., 2000: 13-25; Jolls, 2007: 117). Moreover, people might have bounded will power and might be tempted and myopic (Jolls, 2007: 120).

Behavioural economics also informs that a distortion in individual choices involving the risk of being infected with Covid-19 could arise if people (or MS governments) do not understand the risk entailed, such that a systematic bias emerges in their risk beliefs. The literature suggests that risk underestimation leads to overly risky activity, whereas risk overestimation leads to an excessive level of activity (Viscusi, 2007). Such errors may be critically important with respect to catastrophic events, which tend to have a low probability of transpiring (Camerer and Kunreuther, 1989; Posner, 2004). Moreover, the literature also suggests that where there is a risk of mortality (like with Covid-19), the general pattern is that people overestimate small risks and underestimate large ones (Fischhoff et al., 1981). Lichtenstein et al. (1978) report that people tend to overestimate small risks like those of lightning strikes and underestimate more consequential risks such as the risk of a pathogen.

Alongside this, Gruber and Köszegi (2001) argue that people suffer from time inconsistency in their choices. They give an example where people exhibit hyperbolic discounting, whereby the level of time preference for immediate rewards is much greater than for deferred ones (Gruber and Köszegi, 2001; Becker et al., 1994). Further, Bernheim and Rangel (2004) employ cognitive psychology and show that people engage in harmful behaviour due to a mistaken activity decision.

In addition, Ritov and Baron (2000) studied the observed reluctance of subjects to vaccinate and identified two persistent biases. One bias is the tendency of humans for omissions over commissions, especially when either choice might cause harm, where humans choose not to take precautions even if such a precaution (vaccination) would reduce the overall risk of harm (Ritov and Baron, 2000: 168). The second identified bias is the human tendency to withhold action when missing information cannot be obtained (Ritov and Baron, 2000: 169).

These findings also offer an additional behavioural rationale for people's systematic underestimation of the severity of the risk brought by Covid-19 and from a behavioural perspective help answer the question of why people are disobeying or circumventing the self-isolation and other social distancing instructions.

\section{Economics of federalism and the optimal vertical allocation of competences}

All regulatory systems require that several different tasks be performed, and so important structural issues arise in determining how these tasks are to be allocated to various institutions. The law and economics of federalism (Faure and Pertain, 2019) informs us regarding which institutional arrangements can assist in implementing the public interest goals of regulation and the extent to which they offer protection against the subversion of the law to meet the demands of private interests (Ogus, 2004: 99). Moreover, the law and economics of federalism offers guidance on the question of whether the appropriate source of regulatory rulemaking should be located in Brussels or in Rome. In other words, the economic theory of federalism has become the starting point for most scholarly and policy discussions on how best to organise the federal state (Inman and Rubinfeld, 2017: 73). The goal is to correct market failures through government action, and its guiding principle is to assign policy responsibility to the lowest level of government able to accomplish the task. The principle was formalised by Oates (1972) as the decentralisation theorem and, with respect to the European Community, as the principle of subsidiarity. From the perspective of economic efficiency, determining which level of government is best suited for managing governmental functions requires balancing of the benefits/costs of decentralised/centralised political structures (Inman and Rubinfeld, 1997a, 1997b).

If, for example, citizens' preferences across the European market are homogenous and if there are no political obstacles, detailed uniform rules should be made at the community level (Ogus, 2004). The homogeneity also implies that there are common market failures, a common commitment to redistribution and other non-economic justifications for regulation. Thus, reasons to support complete centralisation are the existence of externalities across jurisdictions (van den Bergh, 1994), scale economies (Coase, 1937), the promotion of coordination and the prevention of 'prisoner dilemma's' games (Whittman, 2006) and the risk of destructive competition between legal rules (a race to the bottom; van den Bergh, 1994). 
However, such conditions will never exist; but neither will the completely opposite situation (i.e. Tiebout's world; Tiebout, 1956) where complete decentralisation would be the optimal regulatory solution exist. The main reasons in support of decentralisation are the diverging preferences of citizens, informational advantages at lower levels of government, accountability, monopoly problems on the side of central government and the importance of the learning process (Whittman, 2006).

Moreover, Wittman (2006: 350) suggests that federal structures (like the EU) are like multi-layered organisations that will not function effectively unless incentives are properly structured.

Thus, as shown, economic arguments do not always offer a clear-cut answer, but offer a useful toolkit for finding the optimal regulatory mix between centralisation and decentralisation. In other words, a poorly designed vertical division of powers undermines the conditions needed for economic growth, prosperity and peaceful coexistence (van den Bergh, 2016).

\section{TOWARDS THE OPTIMAL EUROPEAN PUBLIC POLICY FRAMEWORK}

This section offers several economically inspired and instrumental insights for a better public policy response to tackling the Covid-19 pandemic.

\section{Mitigation of negative externalities and the collective action problem: decentralisation does not work}

The conceptual framework elaborated above shows that in a world of positive transaction costs and asymmetric information, noninternalised externalities generate suboptimal decision-making at the governmental and individual levels, and this might cause serious outbreaks of pathogens and pandemics. Coordinated policy intervention is becoming necessary because such externalities are ex ante not correctly reflected in the decision-making process of governments and/or individuals or on the supply/demand sides of the market, and thus ex post cause an excessive amount of externalities (contagion). Such coordinated intervention should then aim to reduce these negative externalities and be designed to accomplish the optimal level of Covid-19 containment and/or mitigation of its severity.

Which public policies might then induce a Covid-19 externality spreader to take the identified external costs into account, to reduce the tragedy of the commons and override the free-riding problem? First, the key to achieving a social optimum is to induce both individuals and MS governments to restrict the spread of the virus to a socially EU-wide, optimal (not individually optimal) level. Second, in cases of such a superspreading pathogen with negative spillovers reaching every MS in a matter of hours, decentralisation simply does not work. The authority to act and coordinate must be centralised. Third, the identified externalities can be remedied in several different ways and the law offers a large amount of different policy instruments including command and control public regulations, 'suasive' and voluntary instruments and smart regulatory mixes (Faure and Pertain, 2019).

The literature also offers several standard solutions (i.e. social contracts and monitoring mechanisms) to mitigate collective action problems. One way of tackling the free-riding problem is to delegate to a single authority - the leader - the task of policing others and making essential decisions that members of the group cannot manage to agree upon (Alchian and Demsetz, 1972; Simon, 1981: 193). For example, in the current Covid-19 pandemic, the role of such a leader should be taken by the EU Commission or a European health agency that would coordinate the containment actions of different MS. Another solution is to establish a certain common asset as private property and all should agree to reciprocally respect such an allocation (MacKaay, 2015: 205; Ostrom, 1990). The so-called phenomenon of the anti-commons materialises (Heller, 1998, 2008; Leitzel, 2015). Such a common asset could, for instance, be the right not to be infected by Covid-19, which would then be enforced individually (e.g. by demanding to keep a safety distance) among the general population (bottom-up approach). In his path-breaking 'Second treatise on civil government', Locke (1689) in fact argues that individuals should be entitled to claim as their own, and to exclude others from, things that, 'by sweat of their blow', they have extracted from the state of nature.

Further, philosophical analysis shows that such anti-commons capacity effectively reduces the notorious collective action problem (Schmidtz, 1991). Namely, the deliberate establishment of the anti-commons generates numerous owners of rights, each of whom can then prevent and/or enforce unauthorised behaviour or resource use such as measures to contain the spread of Covid-19. Finally, the containment of Covid-19 and mitigation of its severity should also become EU-wide communal ownership and a club good. Namely, the Nobel Prize winner Buchanan (1965) introduced the theory of club goods, like health, which generate the optimal quantity of 
public goods. Sugdeon (1986) suggests that the effective creation of such a club good should be based on a multilateral reciprocity convention combined with the possibility of distinguishing members 'in good standing' from those who are not. Astonishingly, the current EU institutional structure could be adapted to accommodate and generate such a health club good capacity.

In addition, Taylor $(1987,1982)$ identifies three characteristics that must be fulfilled to master a collective action problem: (a) individual members have to share certain values and beliefs; (b) they must have many direct relationships with one another and (c) their relationships should involve a minimum of reciprocity. Obviously, the EU meets all of these requirements, and hence, the containment and mitigation of infectious diseases should, also in line with the literature, become an EU-wide-provided and EUwide-enforced club good. However, it should be stressed that such an 'institution' works in as much as every MS is sure that all the other MS know of and are complying with it. Hence, the formation of a legally binding and centrally enforceable agreement to that effect among the MS appears to be necessary.

\section{Economics of federalism: efforts to contain Covid-19 should be coordinated at the EU level}

Almost 20 years ago, professors Faure (1998), van den Bergh (1994) and Ogus (1999) expressed serious concerns with regard to the EU's levels at which, within the Union, different rules and standards have been established and with respect to the types of subject matters that have been regulated at the centralised (EU) level. They emphasised the enormous importance of the normative issue of the efficient level of harmonisation or subsidiarity of EU decision-making and called for a rigorous investigation of the costs/benefits of the EU's top-down harmonisation policies which should lead to better, more efficient vertical allocation of powers between the EU and the MS (Faure, 1998; Ogus, 1999). In particular, they stressed that the case for the institutionally, EU-led harmonisation of broad-range policies might be weaker than was assumed at that time and that, on the other hand, it is completely missing from the spheres of healthcare protection, border protection and common defence. More recently, professor van den Bergh (2018) and Kovac (2019) suggested that the EU has broadened its regulatory powers in certain domains beyond what is needed to maximise the welfare in the MS, but has failed to exercise these powers at times they would indeed maximise the welfare of EU citizens.

Expressed differently, currently in Europe, each MS is applying its own measures to address the coronavirus pandemic. As to the optimal regulatory mixture, the starting point in the economics of federalism is that decentralisation is to be preferred for certain areas that were previously discussed since it may better satisfy the divergent preferences of $\mathrm{EU}$ citizens, economise on informational advantages, introduce accountability, prevent rent-seeking and moral hazard, and enable learning effects and healthy competition among different MS' regulatory regimes. Yet, on the other hand, centralisation offers other advantages. Namely, scale economies, reduced transaction costs, internalisation of negative spillovers and cross-border negative externalities (like the spread of Covid-19), the free market and the prevention of a destructive, race-to-the-bottom competition among legal regimes are just some of the reasons for greater centralisation.

Moreover, as our conceptual framework suggests, the materialisation of negative externalities (Covid-19 contagion) accompanied by the failure of private law prima facie demands the EU step in by coordinating regulatory intervention in the public interest (Ogus, 2004). Such an EU intervention might also overcome the current potential inadequate MS commitment level (caused by the absence of shared mental models).

In addition to the above, the economics of federalism offers substantive arguments in support of broadening the EU's regulatory powers. These arguments identified the common policy for the containment of infectious diseases as an obvious candidate for centralisation in order to overcome the considerable interstate externalities. We argue that the economics of federalism in the current Covid-19 crisis of biblical proportions is particularly relevant by offering a powerful set of arguments for the EU to hold centralised, coordinative competences, so as to reduce needless transaction and organisational costs, internalise negative spillovers and crossborder negative externalities, while preventing any destructive, race-to-the-bottom or race-to-the-top competition among different political regimes in MS. Of course, one may wonder whether such an action is politically feasible in instances where MS resist any centralisation efforts required to deliver essential public goods. Namely, Scartascini and Tommasi (2012), for example, show that even in the presence of second best institutionalised policymaking, the cost of using alternative political technologies to avoid overcoming collective action failures might be too low to foster Pareto-optimum policy sets. However, the arguments raised herein call for strongly institutionalised, centralised EU action given sufficient support to enable it to become instrumental in containing the spread of the pathogen or mitigating its severity. In other words, outbreaks of pathogens and pandemics are one area in which the central EU level clearly has a comparative advantage with respect to lower levels of government. 


\section{Fast and fundamental change: European Centre for Disease Prevention and the EU Health Agency}

We have shown that economic arguments about the need to mitigate negative externalities and collective action problems coupled with the insights provided by the economics of federalism indicate that a coordinated EU-level approach to tackling the Covid-19 pandemic may be optimal. EU currently lacks ex ante rules specifying procedures for potential pandemics. This implies that a more discretionary role might be granted to the EU Commission to determine the optimal policy response and to allocate the necessary expenditures. Our conceptual framework also implies that an EU infectious disease response mechanism must be established if the notorious collective action problem is to be overcome. Such a mechanism should be activated the moment a pandemic or other crossborder health emergency arises. At the heart of such a mechanism, there should be a single European Health Agency or even, as for example found in the USA, a 'European Centre for Disease Prevention and Control' that is properly funded, staffed and equipped with a legal mandate to act - an agency that does more than simply coordinate national efforts, but is able to take all emergency measures, provide necessary medical help and allocate all resources possible across the continent to keep Europeans safe (Verhofstad, 2020), from issuing mandatory common rules to limiting the spread of the crisis, pooling medicines, supplies, medical staff and hospital equipment through to temporarily closing (partly or completely) the EU's borders. Such tools might have allowed the proposed agency to limit the spread of Covid-19 after it started in northern Italy.

Moreover, changes should be introduced in EU institutions and the related procedural legislation that enable superfast and efficient reactions to potential outbreaks of infectious diseases. For example, the recent saga of the European Commission's joint medical equipment procurements that consume weeks of precious time to materialise indicates the current state of affairs. Unfortunately, these joint procurements came too late for many Italian victims in Lombardy who suffered and died en masse in the first weeks of the outbreak.

Further, the establishment of the proposed European response mechanism would, as stressed by Verhofstad (2020), have to be accompanied by increased security along the EU's external borders. While investigating the Middle East Respiratory Syndrome (MERS) that had a similar social impact as COVID-19, Kim (2016) suggests that harmonising the different strategies applied is for the greater good in terms of better understanding and preventing the transmission of any transnational virus. Yet, in order for a large organisation like the EU to ensure conformity and coordination, political trust must first exist internally if it is to sprout on a national level (Willer, 2009; Kim et al., 2017).

In addition, the society and the EU institutions generally incur a very significant psychological and political cost when the hospitals in a certain MS become unable to treat a large number of patients. Many EU citizens are losing faith in the EU's institutions and its political capacity to act effectively if MS stand back and deliberately allow this to happen. Also, trust in national political institutions is really low across Europe (as seen in surveys), so it comes as no surprise that trust in all institutions at all levels (including the World Health Organization and the United Nations) is so low. Such complete lack of trust in institutions creates fertile grounds for all different materialisation of nationalisms and even fascism.

In other words, during this Covid-19 pandemic, the EU might lose its legitimisation in the hearts and souls of its citizens. Hence, much can also be politically gained by acting effectively, containing the spread, reducing its severity and staying below hospital capacity levels, apart from the considerably higher mortality.

\section{Social distancing measures as an additional solution to the collective action problem}

In response to the spread of Covid-19, states are forced to make an internal decision on the movement of people, that is, whether to implement social distancing measures (restricted intra-state movement and confinement to homes). These health measures have been imposed with the hope that it will limit the peak level of infection in the population and spread the infection out over time, thereby allowing medical infrastructure capacity at a given time to not become stressed to the point of failure.

However, in the last few decades, we have faced several virus outbreaks which have created constant concerns that a pathogen might emerge that is easily transmissible and lead to a pandemic with high mortality. Still, the lack of institutional mechanisms, long-term planning and willingness to invest in healthcare have all come to light with the COVID-19 outbreak (Peeri et al., 2020). The current events have created political tensions among the MS that have pushed the authorities at home to establish national-level 
pandemic prevention planning. One of the steps in pandemic prevention planning includes social distancing measures along with hygiene compliance, which appear to be limited tools at this time of need (Braunack-Mayer et al., 2010).

In order to reduce the free-riding phenomenon and collective action problems, the literature describes centrally coordinated and regulatorily enforced social distancing interventions like isolation and quarantine including school closures, travel restrictions, border closures, lower workplace participation and limited social communications and contacts (Kelso et al., 2009). It also suggests that for an epidemic with an R0 value of 1.5, a combination of all four social distancing measures could reduce the final level of new infections from 33\% to below 10\% if introduced within 6 weeks of the appearance of first case (Kelso et al., 2009).

Lai et al. (2020) in their recent study even argue that had China implemented the above-mentioned social distancing measures 3 , 2 or 1 week immediately after the outbreak, the number of new infections would have dropped by 66\%, 86\% and 95\%, respectively. Namely, lax constraints in the early stages of a pandemic can drastically reduce the effectiveness of such measures (Lee, 2020). Cheryl and Baumann (2020) suggest that such policy interventions should be applied until the transmission slows down and the health institutions are able to manage the overwhelming patient numbers. To sum up, social distancing policies are an additional (and very effective) alternative policy mechanism that attempts to solve the mentioned collective action problem, free riding and the phenomenon of negative externalities.

\section{Covid-19 warnings and risk communication policies}

One of the additional ways to supplement previously discussed centralised EU regulatory intervention and regulatorily enforced social distancing measures on containing the spread of Covid-19 is to use informational policies. Namely, the literature suggests that hazard warnings provide people with the information they need in order to take appropriate precautions with respect to the hazardous activity (Viscusi, 2007). These warnings should provide new information on the pathogen's hazards in an expedited and convincing way that then forms accurate risk beliefs (Adler and Pittle, 1984). Both citizens and governments will thereby be able to process the threat brought by Covid-19 more rationally (take precautions) and adjust their behaviour accordingly. In addition, Kim et al. (2017) contend that inter-agency risk communication strategies and online risk communication are an important means for improving inter-agency efforts in response to a virus outbreak. They also argue that public agencies must adopt adequate interagency risk communication strategies to access core information in order to prevent the transmission of an infectious disease with a transboundary nature (Kim et al., 2017).

In addition, while the full extent of a pandemic might be unknown, the literature suggests that social supports and behavioural plans may be able to reduce the negative psychological effects of isolation, potentially reducing any disincentive to isolate (Lunn et al., 2020). Further, public-spirited behaviour is more likely to develop with frequent communication of what is 'best for all', a strong group identity, and social disapproval of noncompliance (Lunn et al., 2020). In contrast, disobedience is typically due to doubts about the negative effects of the virus. Obviously, such information spreading at the speed of light on social media plays a monumental role in amplifying such unwanted doubts (Lunn et al., 2020).

However, hazard warnings have significant shortcomings by being subject to the individual's cognitive limitations and information-processing capacities (Bettman et al., 1987). The literature shows that limitations on people's working memory make it important for warnings to be clear, well organised and easy to process (Bettman et al., 1987; Viscusi and Magat, 1987).

Summing up, the effective mitigation and containment of the spread of Covid-19 boils down to effective and centrally coordinated EU public policy intervention.

\section{CONCLUSION}

Covid-19 is sweeping over the European continent with the entire EU facing an unprecedented human tragedy. This paper has attempted to show that the economics literature on federalism, informational failures, negative externalities, collective action problems and irrational choice offers an alternative view on the current political discussion on the Covid-19 pandemic and the related role of the EU. The identified sources of market failures, irrational decision-making, collective action problems and suboptimal allocation of competences give the impetus for an active, coordinative role of EU public policy in containing the spread of Covid-19 and reducing its severity. 
The paper also addresses the role of European public policy in dealing with the Covid-19 pandemic. Currently in Europe, each MS is applying its own measures to address the pandemic. This is decentralised decision-making, which leads to socio-political tensions among the MS. Moreover, the slow and uncoordinated response to the Covid-19 pandemic might see the EU lose some of its legitimisation in the eyes of its citizens. Accordingly, there is also a huge political premium on acting effectively, containing the spread, mitigating its severity and staying below hospital capacity levels, apart from the significantly higher mortality. The paper argues that to reduce these tensions, it is vital that the European public policy changes fast and fundamentally; otherwise, it might even simply cease to exist. Our conceptual framework suggests that the materialisation of negative externalities (including the Covid-19 contagion) accompanied by the failure of private law prima facie demands the EU step in with coordinated regulatory intervention in the public interest. Moreover, the described notorious collective action problem and related free-riding phenomenon are distorting the MS' current collective efforts and result in the suboptimal performance of their containing and mitigating actions. The unprecedented outbreak of this superspreading pathogen thus calls for increased EU central competences and a corresponding Europe-wide coordinated response. The paper argues that the Covid-19 pandemic is one area in which the central EU level has a comparative advantage compared to lower levels of government. Finally, the probability of second and third waves of the Covid-19 outbreaks means that it is even now not too late to take the steps we are suggesting.

\section{REFERENCES}

Adler, R. S., and Pittle, R. D. 1984. "Cajolery or command: are education campaigns an adequate substitute for regulation?" Yale Journal on Regulation, 1(2), 4 .

Akerloff A. G. 1970. "The Market for Lemons: Quality, Uncertainty and the Market Mechanism," 84 Quarterly Journal of Economics 488.

Alchian, A. A., and Demsetz, H. 1972. "Production, information costs, and economic organization," 62 American Economic Review, pp. 777-795.

Allais, M. 1953. "Fondements d'une Theorie Positive des Choix Comportant un Risque et Critique des Postulats et Axiomes de L'Ecole Americaine," 21 Econometrica 4, pp. 503-546.

Becker, G. S., Grossman, M., and Murphy, K. M. 1990. "An empirical analysis of cigarette addiction" (No. w3322). National Bureau of Economic Research.

Bergh van den, R. 2016. "Farewell Utopia? Why the European Union should take the economics of federalism seriously". Maastricht Journal of European and Comparative Law, 23(6), 937-964.

Bergh van den, R. 2018. "The roundabouts of European law and economics," Eleven International Publishing, at pp. 21-28.

Bernheim, B. D., and Rangel A., 2004. "Addiction and cue-triggered decision processes". American economic review, 94(5), 1558-1590.

Bettman, J. R., Payne, J. W., and Staelin, R. 1987. "Cognitive considerations in presenting risk information". In Viscusi W. K. and Magat W. A., "Learning about Risk: Consumer and Worker Responses to Hazard Information" Cambridge: Harvard University Press.

Braunack-Mayer, A. J., Street, J. M., Rogers, W. A., Givney, R., Moss, J. R., and Hiller, J. E. 2010. "Including the public in pandemic planning: a deliberative approach." BMC public health, 10(1), 501. [online] (cit. $6^{\text {th }}$ April 2020)

Braw, E. 2020. The EU Is Abandoning Italy in Its Hour of Need. Foreign Policy, March, 14. [online] (cit. $4^{\text {th }}$ April 2020)

Lee, B.Y. (2020). How Long Should Social Distancing Last? When Will COVID-19 Coronavirus End? Published on: 26/03/2020

Buchanan, J. M. 1965. "An economic theory of clubs." Economica, 32(125), 1-14.

Camerer, C. F., and Kunreuther, H. 1989. "Decision processes for low probability events: Policy implications". Journal of policy analysis and management, 8(4), 565-592.

Saenz, C. and Baumann, J. Gottlieb Says Social Distancing Must Go On Until Infection Slows. Published on: March 29, 2020, 8:19 PM GMT+2 Updated on March 29, 2020, 11:24 PM GMT+2, [online] (cit. $6^{\text {th }}$ April 2020)

Coase, R. H. 1937. "The Nature of the Firm." 4 Economica 386.

Coase, R. H. 1959. "The Federal Communications Commission." 2 Journal of Law and Economics 1, 1-40.

Coase, R. H. 1995. "The nature of the firm. In Essential readings in economics," (pp. 37-54). Palgrave, London.

Cohen, L. 1991. "Holdouts and free riders". The Journal of Legal Studies, $20(2), 351-362$.

Cooter, R., and Ulen, T. 2016. "Law and Economics," $6^{\text {th }}$ ed., Pearson, pp 40-42.

De Geest, G. (Ed.). 2011. Contract law and economics (Vol. 6). Edward Elgar Publishing. 
Delors Jacques 2020. "The germ is back," AFP.

Demsetz H. 1967. "Toward a theory of property rights," 57 American Economic Review Papers and proceedings 347, pp. 351-353.

Denzau, A. T., and North, D. C. 1994. "Shared Mental Models: Ideologies and Institutions." Kyklos, 47(1), 3-31.

Diamanti, I., 2020. "Bussole," La Repubblica.

Dixit, A., and Nalebuff, B. J. 1991. "Thinking Strategically: The Competitive Edge in Business, Politics and Everyday Life." New York: Norton.

Eggertsson T. 1990. "Economic behaviour and institutions," Cambridge University Press.

Ellsberg, D. 1961. "Risk, ambiguity, and the Savage axioms". 75 The Quarterly Journal of Economics 4, 643-669.

Faure, M. G., and Partain, R. A. 2019. "Environmental Law and Economics: Theory and Practice." Cambridge University Press: Cambridge.

Fischoff, B., Lichtenstein, S., Slovic, P., Derby, S., and Keeny, R. 1981. Acceptable Risk. New York: Cambridge University Press.

Fudenberg D. and Tirole J. 1996. "Game theory," MIT Press: Boston.

Gordon H. S. 1954. "The Economic theory of a Common-Property Resource: The Fishery," 62 Journal of Political Economy 2, 124-142.

Gruber, J., and Köszegi, B. 2001. "Is addiction "rational"? Theory and evidence." The Quarterly Journal of Economics, 116(4), 1261-1303.

Hardin, G. 1968. "The tragedy of the commons." Science 162(3859), $1243-1248$.

Heller, M. 2008. "The gridlock economy," New York, Basic Books.

Heller, M. 1998. "The tragedy of anti-commons: property in the transition from Marx to markets." 111 Harvard Law Review, pp. 621-688.

Hirshleifer, J. 1984. "Price theory and applications." $3^{\text {rd }}$ ed., Cambridge: Cambridge University Press.

Inman R. P., and Rubinfeld D. L. 2017. "Economics of Federalism," in Francesco P. (ed.), The Oxford Handbook of Law and Economics. Volume 3: Public Law and Legal Institutions, Oxford: Oxford University Press.

Inman, R. P., and Rubinfeld, D. L. 1997. "Rethinking federalism." Journal of economic perspectives, $11(4), 43-64$.

Inman, R. P., and Rubinfeld, D. L. 1997. "The Political Economy of Federalism," in Mueller Denies (ed.), "Perspectives on Public Choice: $A$ Handbook," Cambridge: Cambridge University Press, pp. 73-105.

Jackson H. E., Kaplow L., Shavell S. M., Viscusi W. K. and Cope D. 2003. "Analytical Methods for Lawyers." New York: Foundation Press.
John L. 1988. "Two treatises of government," 1690, Ed. Laslett, P. Cambridge: Cambridge University Press.

Jon, E. 2007. Explaining Social Behavior: More Nuts and Bolts for the Social Sciences. " $2^{\text {nd }}$ ed., Cambridge: Cambridge University Press.

Jolls, C., Sunstein, C. R., and Thaler, R. 2000. "A Behavioral Approach to Law and Economics," in Sunstein, R. C. (ed.), "Behavioral Law and Economics," Cambridge: Cambridge University Press, pp.13-58.

Jolls, C. 2007. "Behavioral law and economics," in D., P., and H. Vartiainen (eds.), "Behavioral Economics and its Applications," New Jersey: Princeton University Press, pp. 115 et seq.

Kelso, J. K., Milne, G. J. and Kelly, H. 2009. "Simulation suggests that rapid activation of social distancing can arrest epidemic development due to a novel strain of influenza." BMC public health, 9(1), 117. Published: 29 April 2009 BMC Public Health 2009, [online] (cit. $6^{\text {th }}$ April 2020)

Kim, O. J. 2016. "Ethical Perspectives on the Middle East Respiratory Syndrome Coronavirus Epidemic in Korea." Journal of Preventive Medicine and Public Health, 49(1), 18.

Kim, K., Andrew, S. A., \& Jung, K. 2017. "Public Health Network Structure and Collaboration Effectiveness during the 2015 MERS Outbreak in South Korea: An Institutional Collective Action Framework." International journal of environmental research and public health, 14(9), 1064.

Kobayashi H. Bruce and Ribstein E. Larry 2007. "Economics of Federalism," Cheltenham: Edward Elgar.

Kovac, M. 2019. "The Brexit Fiasco and the Failure of Article 50 of the Treaty on the Functioning of the European Union." Baltic Journal of Law and Politics, 2019, vol. 12, iss. 1, p. 172-192.

Kreps, D. M. 1990. "A course in microeconomic theory." New Jersey: Princeton University Press.

Lai S, Ruktanonchai N and Zhou L (2020). Effect of non-pharmaceutical interventions for containing the COVID-19 outbreak: an observational and modelling study.

Leitzel, J. 2015. "Concepts in law and economics." New York: Oxford University Press.

Lichtenstein, S., Slovic, P., Fischhoff, B., Layman, M., \& Combs, B. 1978. "Judged frequency of lethal events". Journal of experimental psychology: Human learning and memory. 4(6), 551.

Luce, R. D., and Raiffa, H. 1957. "Games and decisions." New York: Wiley. Lucchese, M., and Pianta, M. 2020. "The Coming Coronavirus Crisis: What Can We Learn?. Intereconomics: Review of European Economic Policy, 55(2), 98-104. 
Lunn, P. D., Belton, C. A., Lavin, C., McGowan, F. P., Timmons, S., and Robertson, D. A. 2020. "Using Behavioral Science to help fight the Coronavirus." Journal of Behavioral Public Administration, 3(1).

MacKaay E. 2015. "Law and Economics for Civil Law Systems," Cheltenham, Edward Elgar, pp. 205-207.

Magen S. 2015. "Game theory and collective goods," in Towfigh V. Emanuel and Niels Petersen (eds.), "Economic methods for lawyers," Cheltenham: Edward Elgar, pp.78-8o.

Markowitz, H. 1952. "The Utility of Wealth." 6o Journal of Political Economy 2

Markowitz, H. 1952. "Portfolio Selection," 7 Journal of Finance 1, pp. 77-91.

Mathieu, J. E., Heffner, T. S., Goodwin, G. F., Salas, E., \& Cannon-Bowers, J. A. (2000). "The Influence of Shared Mental Models on Team Process and Performance." Journal of Applied Psychology, 85(2), 273-283.

Miller, R. L., Benjamin, D. K., \& North, D. C. 2017, "The Economics of Public Policy issues," $20^{\text {th }}$ ed., Pearson.

Mukand, S. W., and Rodrik, D. 2020. "The Political Economy of Liberal Democracy." The Economic Journal, 130 (627), 765-792.

Oates, W. E. 1972. "Fiscal Federalism," London, Harcourt Brace Jovanovich.

Ogus, A. I. 2004. "Regulation: Legal Form and Economic Theory," Hart Publishing, at p.99.

Olson M. 1965. "The Logic of Collective Action." Boston, Harvard University Press.

Ostrom, E. 1990. "Governing the commons - the evolution of institutions for collective action," Cambridge University Press.

Peeri, N. C., Shrestha N. and Rahman M. S., et al. The SARS, MERS and novel coronavirus (COVID-19) epidemics, the newest and biggest global health threats: what lessons have we learned? [online] (cit. $6^{\text {th }}$ April 2020)

Pigou, A. C. 1932. "The economics of welfare," London, Macmillan

Posner, R. A. 2004. Catastrophe: risk and response. Oxford University Press.

Posner, R. A. 2014. "Economic analysis of law." Wolters Kluwer law \& business.

Regling, K. 2020. "The time for EU solidarity is now," Athens, Ekathemirini. [online] (cit. $4^{\text {th }}$ April 2020)

Ritov I., and Baron, J. 2000. "Reluctance to vaccinate: omission bias and ambiguity," in Sunstein, R. C. (ed.), "Behavioral Law and Economics," Cambridge University Press, pp.168-187.
Rosen K., M. and S. 1997. "Microeconomics," $3^{\text {rd }}$ ed., McGraw-Hill/Irwin.

Scartascini, C., and Tommasi, M. 2012. "The Making of Policy: Institutionalized or not?" American Journal of Political Science 56(4), 787-

801.

Schelling T.C. 1960. The Strategy of Conflict. Cambridge: Harvard University Press.

Schelling, T.C. 1960. "Strategy of Conflict," Harvard University Press.

Schmidtz D. 1991. "The limits of government - an essay on the public goods argument,"Westview Press.

Simon, H. A. 1981. "The architecture of complexity," in Herbert, S. A. (ed.), "The sciences of the artificial," $2^{\text {nd }}$ ed., MIT Press, pp. 193-229.

Sugden, R. 1986. "The economics of rights, co-operation \& welfare," Basil Blackwell.

Sunstein, C. R. 2000. "Behavioral Law and Economics," Cambridge University Press.

Taylor, M. 1987. "The possibility of co-operation," Cambridge University Press.

Taylor, M. 1982. "Community, anarchy and liberty," Cambridge University Press.

Tiebout C.1956. "A Pure Theory of Local Expenditure," 64 Journal of Political Economy 416.

Thaler, R. 1980. "Toward a positive theory of consumer choice," 1 Journal of Economic Behavior and Organization I, pp. 39-6o.

Tversky, A. and Kahneman, D.1979. "Prospect theory: An analysis of decision under risk." Econometrica, 47(2), 263-291.

Verhofstad G. 2020. "Time of coronavirus shows importance of being European," EU Observer.

Viscusi, W. K. and W. A. Magat (eds.) 1987. "Learning about the risk: consumer and worker responses to hazard information," Harvard University Press.

Viscusi, W. K. 1987. "Fatal trade-offs: public and private responsibilities for risk," Oxford University Press.

Viscusi, W. K. 2007. "Regulation of health, safety and environmental risks," in Polinsky, A. Shavell M. and S. (eds.), "Handbook of law and economics," Vol. 1., New York: North-Holland.

Wittman D. 2006. "Economic Foundation of Law and Organization," Cambridge: Cambridge University Press, at p. 350.

Willer, R. 2009. "Groups reward individual sacrifice: The status solution to the collective action problem". American Sociological Review, 74(1), 23-43. 
Yarlagadda, S. 2010. "Using many-body entanglement for coordinated action in game theory problems." In Econophysics and Economics of Games, Social Choices and Quantitative Techniques (pp. 44-51). Springer, Milano. 